\section{ECONOMICS}

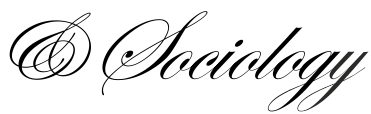

\title{
DO EDUCATION LEVELS MATTER ON INDONESIAN ECONOMIC GROWTH?
}

\author{
David Mendy, \\ Faculty of Economics and Business, \\ Gadjah Mada University, \\ Indonesia \\ E-mail:davidmendy91@gmail.com \\ Tri Widodo, \\ Center for Southeast Asian Social \\ Studies (CESASS), and Faculty \\ of Economics and Business, Gadjah \\ Mada University, \\ Indonesia \\ E-mail:widodo.tri@ugm.ac.id
}

Received: January, 2018

1st Revision: March, 2018

Accepted: August, 2018

DOI: $10.14254 / 2071-$

789X.2018/11-3/8

\begin{abstract}
Arising from the questions "Would all types of human capital affect economic growth identically? And which type of schooling - primary, secondary, or tertiary - should public policy promote?", this study examines the nexus between different educational levels and Indonesia's economic growth over a reference period 1984-2014. During this period, education expansion took place at all three levels of education reflecting structural changes tied within the policies under the Millennium Development Goals (MDG's) as the key and powerful factor for sustainable economic development. The study applies the augmented Lucas endogenous growth model and employs the autoregressive distributed lag model. The empirical analysis reveals a long-run relation between education and economic growth. The estimated long-run and short-run elasticity of different education levels reveal that, overall, human capital structure in Indonesia is still at the stage of promoting economic growth and identifies tertiary education as the main level for development. The findings reveal that education level matters to economic growth. Further, the empirical evidence helps shed light on why empirical studies have failed to find a significant relationship between schooling and economic growth.
\end{abstract}

JEL Classification: O15, $\mathrm{O} 24$

Keywords: education levels, economic growth, ARDL, Indonesia

\section{Introduction}

The relationship between economic growth and education is often of interest when it comes to economic analysis. Adam Smith in the eighteenth century and Alfred Marshall in the nineteenth century, both dealt with the question of how individual investments in "education" effect the wealth of nations (Miller, 2007). Education makes businesses more efficient, competitive and productive by making the workforce more flexible; it allows scientific knowledge and technological innovations to penetrate and nations to "transit" from less skilled and labor-intensive to highly skilled and capital-intensive operations. Indeed, educated workforce can adapt to changes more quickly when the situations require. Also, educated workforce communicates better and allows countries absorb imported technologies to perform specific production processes that require sophisticated operations (Hassan and Ahmed, 2008). Similarly, education promotes positive externalities by encouraging individuals and households share the country's interests; also, education lowers infant mortality rates, prevents the spread 
of communicable diseases, balances fertility rates, and finally, promotes tolerance, peace, and democracy. It enables the acquisition of skills required for higher wages; empowers people to perform more complicated and high-tech tasks rather than standard ones; helps them adapt to the latest technologies and production practices, and allow them to be overall more mobile and enterprising (Feldman, Hadjimichael, \& Lanahan, 2016).

Throughout the twenty-first century as (Krueger \& Lindahl, 2001) mentioned in their survey, modern professional economists have attempted to develop empirical estimates of how human capital affects economic growth. For instance, Mincer (1974), Mankiw, Romer, and Weil (1992) to mention but few have made their reputation by studying the issues of individual returns to investment in education. Hawkes and Ugur (2012) have proposed the idea that human capital offers many benefits for people, society and the economy, i.e., education regarding personal health, decreasing crime rates and environmental preservation is the key determinant of economic growth and development. Moreover, it is commonly recognized that the primary mechanism for nurturing human skills and capabilities is the formal education system. As of today, most of the third world economies come to believe that education development is crucial for national economic development (Asteriou \& Agiomirgianakis, 2001).

The motivation for this study has been to examine empirically the question: Do education level matters for Indonesia's economic growth? Indonesia is an interesting case study in this context for several reasons. Firstly, Indonesia's education system includes various forms, types, and levels of education (Dharma, 2008). Indonesian basic education (primary and secondary) covers nine years (from 7 to 15 years old) of schooling in both formal and informal education systems in which the essential objective is to nurture learner's cognitive abilities, personality, character, skills to work independently. The enrolment statistics has risen over the past several decades given the current emphasis on educational attainment for all by the United Nations as part of the MDGs. The percentage of primary school enrolment was close to 100 percent in 2010, as opposed to 70 percent back in 1975 (Elias \& Noone, 2016). However, significant obstacles remain at the secondary level, with girls more vulnerable to drop out. More to the point, over 6.8 million kids at the age appropriate for secondary education are drop-outs, in remote rural Indonesia especially. Again, efforts to improve the education in Indonesia have encountered various obstacles such as imitations of learning skills; insufficient number, quality and welfare of teachers; and inadequate budget provision for education (Firman \& Tola, 2008). Secondly; in the early 2000s after the political and economic crises priority has been taken by the Indonesian government to enhance education quality, accessibility, equity, and accountability. As a result, major reforms were taken place in accordance with the Law no. 23 under the National Education System (NES). These reforms were concentrated on the standard school curriculum content, facilities, funding, learning capability of graduates, quality control, among other issues (Firman \& Tola, 2008). Finally; the tertiary education includes several broad categories: public or private, secular or religious, while types of academic specialization include academic, polytechnic, institute, college, and university (Altbach \& Umakoshi, 2004; Moeliodihardjo, 2015). Academic and polytechnic levels are vocational (D1-D4), with graduates getting their diplomas after the completion of a four-year study program, undergraduate degree (S1) programs also last for four years, with additional two years for master's program (S2) and further extra three years for doctorate program (S3) (Asian Development Bank, 2015). Therefore, in a broader perspective, the relevance of education remains a concern and a challenge for the Ministry of Education and Culture (MoEC), and also for international organizations striving for effective organization of economic cooperation and development among nations.

From the empirical point of view, Ramcharan (2004) developed a new analytical structure comprised of different levels of human capital and concluded that the average years of schooling could mark the potentially significant differences in the composition of human capital, and this may help us apprehend why most empirical studies have failed to confirm a 
significant connection between education and economic growth. Furthermore, since human capital is generally treated as a homogenous concept, little is still understood about how various education levels (primary, secondary and tertiary) affect the overall development of a country. The contribution of this study is as follows; unlike previous studies on Indonesia (see McMahon, 1998; Bayhaqi, 2000; Kawuryan, 2001; Kasri, 2011; Reza \& Widodo, 2013) this paper, firstly, used times series data from 1984 to 2014 and employed a variant of the augmented Solow model as proposed by Mankiw, Romer, and Weil. The model follows the one used by (Lucas, 1988) in considering additional variables like labor and capital thus reducing the variable omission bias. Secondly, this paper has employed the Autoregressive Distributed Lag (ARDL) model developed by (Pesaran, Shin, and Smith, 2001) which is suitable for handling variables integrated at a different level and allows for the estimation of both short-run and long-run coefficients. Finally, the empirical evidence endorses the hypothesis that human capital is certainly related to economic growth, but the results were uneven across various levels of education. Thus, the paper concludes that failure to account for these differences may have serious ramifications on the economic growth of Indonesia.

The rest of the paper is organized as follows: Section 2 reviews the literature. Section 3 presents the methodology, data and estimation procedures. Section 4 presents the empirical results and their discussion. Finally, section 5 presents the conclusions and recommendations.

\section{Literature review}

The central theoretical research on the interconnection of the human capital and growth can be sum up in the following: (i) the human capital intensifies growth (Lucas, 1988); (ii) economic growth rest on the prevailing human capital generating new knowledge (Mankiw, Romer \& Weil, 1992); (iii) the human capital promotes the copying or adaptation of new or innovative technologies (Nelson \& Phelps, 1966); (iv) the human capital is correlated with the amount of stock accumulated (Azariadis \& Drazen, 1990). For several decades, the effects of human capital on economic growth has been a topic of research both from the macroeconomic perspective (see Pereira and Aubyn, 2004; Odit, Dookhan, \& Fauzel, 2010) among many others, and from the micro perspective (Psacharopoulos, 1995; Bouaissa, 2009) to name but a few. Mankiw et al., (1992) showed that human capital impacts economic growth positively. On the contrary, Benhabib and Spiegel (1994) empirically found human capital, and economic growth is adversely correlated. Several studies opined the inconclusiveness of the empirical findings is mainly influenced by proxies, data and methodology used. Moreover, away from the orthodox practices, recent empirical works have concentrated on the composition of human capital on economic growth and the augmentation of endogenous growth models.

In India, Self and Grabowski (2004) using times series data and utilizing the Granger causality approach on the various level of education, the results indicated a strong causality between primary education and economic growth. Elsewhere, in China, Lau (2010) found that enrolment in primary education stimulates economic growth while investing in secondary and higher education weakly influence economic growth. Likewise, Chi (2008) finds that the tertiary education positively influences GDP growth relative to the primary and secondary education in China. Again, Zhang and Zhuang (2011) using data for 31 provinces of China from 1997-2006 and employing the Generalized Method of Moments (GMM) concludes tertiary education vehemently influence the economic growth of China. Similarly, to another place, Pereira and Aubyn (2004) found that Portugal's economic growth is mainly influenced by tertiary education. In a different place, in Greece for example, Benos and Karagiannis (2016) using census data on education from 1971-2011 and utilizing the Generalized Methods of Moments (GMM) finds that secondary and tertiary education supports productivity positively, whereas primary education adversely impacts productivity. 
In Indonesia, few studies have attempted to study the connection between human capital and economic growth and the mixed results was also found. For instance, Bayhaqi (2000) uses the average years of schooling as a human capital proxy finds that education contributes little to economic growth. Kawuryan (2001) suggest that changes enrolment rate of secondary education in Indonesia is crucial for economic growth. McMahon (1998) finds that primary and secondary education give a significant positive role to the growth of East Asian countries (Indonesia inclusive). Recently, Kasri (2011) utilizing the error correction model concludes that secondary school education gives a higher contribution to economic growth and not primary school education.

In summary, there is no empirical harmony among researchers regarding the composition of education levels on economic growth. The empirical research often finds signs and significance of schooling depending on the sample of observations or the specification model and the empirical approach employed. A standard feature of the studies reviewed is that most of the empirical estimates focus on long-run analysis with little or no emphasis on shortrun analysis. Another observation is the methodological approach some studies used the multivariate method, concerning physical and labor while others have not. Therefore, this study expands on the existing literature in Indonesia by empirically investigating the effects of human capital composition on the Indonesian economic growth utilizing the Autoregressive Distributed Lag (ARDL) model developed by Pesaran et al. (2001).

\section{Methodology}

\subsection{Data}

This study focuses on annual time series data from 1984-2014 mainly due to the complete accessibility of the data for all the relevant variables under consideration. All data is being retrieved from world bank development indicators (WDI). The variables used in this study are; GDP has a proxy for economic growth and development. The human capital composition comprises three proxies; (i) primary education (number of people enroll in primary education both sex), (ii) secondary education (number of student enrolment in secondary education both sex), and (iii) tertiary education (gross enrolment ratio). Physical capital is proxied by gross fixed capital formation (in numbers), and finally the labor force (total number of the labor force). Interpolation is used to fill in missing data. Moreover, Table 1 displays that all the variables are normally distributed.

Table 1. Test for Normality of the Data

\begin{tabular}{lcccc}
\hline Variables & Acronym & No.obs & Jarque Bera -Test & Lilliefors-Test \\
\hline Gross Domestic Product & GDP & 31 & $1.2174(0.5440)$ & $0.0949(0.67)$ \\
Primary Education & PRI & 31 & $0.1399(0.9324)$ & $0.0962(0.65)$ \\
Secondary Education & SEC & 31 & $1.2734(0.5290)$ & $0.1193(0.31)$ \\
Tertiary education & TER & 31 & $3.4773(0.1758)$ & $0.1330(0.17)$ \\
Gross Fixed Capital Formation & GFIX & 31 & $1.0946(0.5785)$ & $0.1090(0.45)$ \\
Labor Force & LFRCE & 31 & $2,0989(0,3501)$ & $0.0941(0.68)$ \\
\hline
\end{tabular}

Source: WDI, Authors' Estimates using Gretel software 


\subsection{Model and Estimation Technique}

Following Lucas (1988) endogenous human capital model, the production function is represented as follows:

$$
Y_{t}=A K_{t}^{\alpha}\left(u H_{t}\right)^{1-\alpha}
$$

Where the standard notion $Y_{t}$ denotes output, $K_{t}$ is the stock of physical capital, $H_{t}$ is human capital stock, $u$ is the fraction of a person time allocated to production, $\alpha$ and $A$ are the parameters, where $A$ is the level of technology. Thus, an augmented version of the Lucas (1988) endogenous growth empirically is written as:

$$
\begin{gathered}
\ln G D P_{t}=\beta_{0}+\beta_{1} \ln P R I_{t}+\beta_{2} \ln S E C_{t}+\beta_{3} \ln T E R_{t}+\beta_{4} \ln G F I X_{t}+ \\
+\beta_{5} \ln L F R C E_{t}+e_{t}
\end{gathered}
$$

\subsection{The Bounds Testing Approach}

The autoregressive distributed lag (ARDL) bounds testing approach is employed to empirically investigate the nexus between the various levels of human capital and economic growth in Indonesia. The ARDL model has some merits relative to most macro-econometrics techniques. Firstly, Pesaran, Shin, and Smith (2001) highlighted the use of the ARDL model for the estimation of level relationships because the model proposes that once the order of the relevant variables has been recognized OLS can estimate the relationship of the variables. Secondly, the order of integration of the relevant variable need not necessarily be the same; specifically, it encompasses variables integrated at a different level I (0) and I (1) except for I (2) variables. Another merit of the ARDL model is that; the unrestricted model of ECM appears to take satisfactory lags that capture the data generating process (commonly abbreviated as DGP) in a general-to-a specific framework of the specification. More to the point, unlike the orthodox cointegration techniques that may suffer from the problems of endogeneity among relevant variables the ARDL model strictly distinguished the dependent variable from the independent variables. Finally, the modification of the order of lags variables is appropriate to correct for the presence of any serial correlation among the variables (Pesaran, Shin \& Smith, 1999).

Therefore, considering the various merits of ARDL Model, the ARDL bounds testing procedure involve two stages: On the one hand, the existence of a long-run relationship of the relevant variables predicted by theory is tested, while on the other hand, comprise testing the short-run relationship of the relevant variables. Hence, without any presumed information on the direction of the long run relationships of the variables, the unrestricted error correction (UEC) regression is estimated using the following equation:

$$
\begin{array}{r}
\Delta(\ln G D P)=\beta_{0}+\beta_{1}(\ln G D P)_{t-1}+\beta_{2}(\ln P R I)_{t-1}+\beta_{3}(\ln S E C)_{t-1}+ \\
\beta_{3}(\ln T E R)_{t-1}+\beta_{4}(\ln G F I X)_{t-1}+\beta_{5}(\ln L F R C E)_{t-1}+\sum_{i=0}^{p} \beta_{6} \Delta(\ln P R I)_{t-1}+ \\
\sum_{i=0}^{p} \beta_{7} \Delta(\ln S E C)_{t-1}+\sum_{i=0}^{p} \beta_{8} \Delta(\ln T E R)_{t-1}+\sum_{i=0}^{p} \beta_{9} \Delta(\ln G F I X)_{t-1}+ \\
\sum_{i=o}^{p} \beta_{10} \Delta(\ln L F R C)_{t-1}+e_{t}
\end{array}
$$

The bounds test approach of cointegration is based on the join F-statistic with an asymptotic distribution that is non-standard with the null hypothesis implying no cointegration relationship and the alternative hypothesis implying a cointegration relation among the variables. Thus, from equation (3), the null and alternative hypothesis is written as: 
$\mathrm{H}_{\mathrm{O}}: \beta_{1}=\beta_{2}=\beta_{3}=\beta_{4}=\beta_{5}=0$ (not cointegrated)

$\mathrm{H}_{1}$ : otherwise (cointegrated)

After the confirmation of a cointegration relationship, the augmented ARDL (m, n, o, $\mathrm{p}, \mathrm{q}, \mathrm{r})$ model is estimated as:

$$
\begin{gathered}
\ln G D P_{t}=\beta_{0}+\sum_{i=1}^{m} \beta_{6}(\ln G D P)_{t-1}+\sum_{i=1}^{n} \beta_{7}(\ln P R I)_{t-1}+\sum_{i=1}^{0} \beta_{8}(\ln S E C)_{t-1}+ \\
\sum_{i=1}^{p} \beta_{9}(\ln T E R)_{t-1}+\sum_{i=1}^{q} \beta_{10}(\ln G F I X)_{t-1}+\sum_{i=1}^{r} \beta_{11}(\ln L F R C E)_{t-1}+e_{t}
\end{gathered}
$$

Here, the maximum number of lags in Eq (3) is maintained to determine the lags (m, n, $\mathrm{o}, \mathrm{p}, \mathrm{q}, \mathrm{r}$ ) in equation (4) chosen by the Akaike Information Criteria (AIC) using Eviews 9 software. After the ARDL model lag is well specified, then the error correction model (ECM) is calibrated. The ECM version of the modified ARDL model captures the short run dynamic relationship between human capital composition and economic growth in Indonesia. The lagged value of the first difference of $\left(\ln G D P_{t}\right)$ on the lagged values of the explanatory variables; primary education $\left(\ln P R I_{t}\right)$, secondary education $\left(\ln S E C_{t}\right)$, tertiary education $\left(\ln T E R_{t}\right)$, gross fixed capital formation $\left(\ln G F I X_{t}\right)$, and the labor force $\left(\ln L F R C E_{t}\right)$ is estimated as:

$$
\begin{aligned}
\Delta(\ln G D P)_{t}= & \beta_{0}+\sum_{i=0}^{m} \beta_{6} \Delta(\ln G D P)_{t-1}+\sum_{i=0}^{n} \beta_{7} \Delta(\ln P R I)_{t-1}+\sum_{i=0}^{0} \beta_{8} \Delta(\ln S E C)_{t-1}+ \\
\sum_{i=0}^{p} \beta_{9} \Delta(\ln T E R)_{t-1}+\sum_{i=0}^{q} \beta_{10} \Delta(\ln G F I X)_{t-1}+\sum_{i=0}^{r} \beta_{11} \Delta(\ln L F R C E)_{t-1}+ & \theta E C T_{t}
\end{aligned}
$$

Where $\beta_{6}, \beta_{7}, \beta_{8}, \beta_{9}, \beta_{10}$ and $\beta_{11}$, represent the short run dynamic coefficients, whereas the $E C T_{t}$ denotes the error correction term or speed of adjustment of convergence towards equilibrium after a given shock. The sign of the $E C T_{t}$ must be negative and significant to ensure convergence of the dynamics to the long-run equilibrium usually ranging from negative one ($1)$ and zero (0). Negative one (-1) signifies perfect and instantaneous convergence while zero (0) means no convergence (see Ahmed et al., 2013).

\section{Empirical results and discussion}

\subsection{Stationary Test}

The prime step for utilizing the ARDL model is affirming that none of the relevant variables is I(2). Thus, to confirm that none of the series is I(2), the Augmented Dickey-Fuller (ADF) and the Akaike Information Criterion is used, and the results are reported in Table 2. However, before proceeding with the Augmented Dickey-Fuller unit root test, it is crucial to specify the null and alternative hypothesis to characterize the constant and trend properties of the data at hand. Thus, Figure 1 examines the data graphically. 

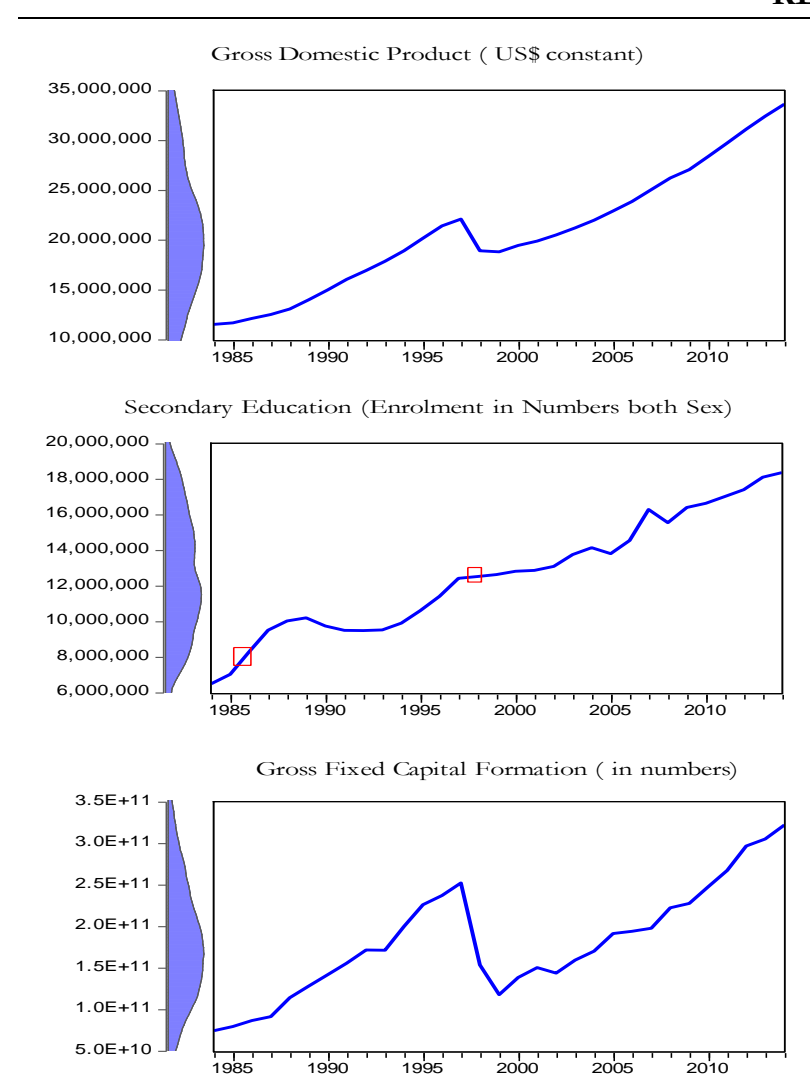

Primary Education (Enrolment in number both sex)

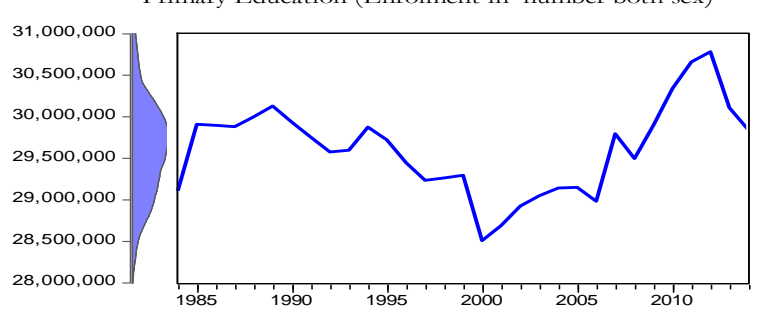

Tertiary Education ( Enrolment in \%)

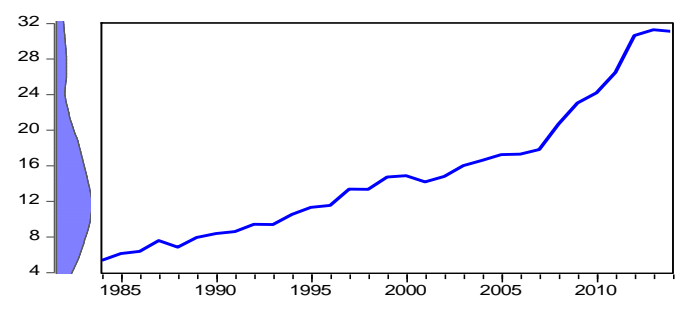

Labor Force (Total in Numbers)

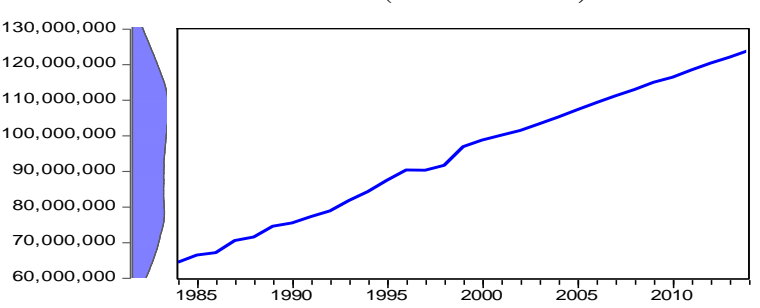

Figure 1. Graphical Representation of The Variables Source: WDI, Authors Graphical representation

Note (i) the secondary education data for [1985 \& 1998] was interpolated using EViews 9 due to missing data. (ii) All Data is in original form.

In Figure 1 (above) all the series indicate an upward trending, suggesting that it will be appropriate to specify an intercept and trend in the ADF unit root model (see Mahadeva \& Robinson, 2004). A look at Figure 1 portrays there is no tendency for mean reverting and variance constancy. Even though such an initial feeling of the data suggests none stationarity at the level, Table 2 reports the results of the ADF unit root test.

Table 2. Unit Root Tests

\begin{tabular}{|c|c|c|c|c|c|}
\hline \multirow{4}{*}{ Variables } & \multicolumn{4}{|c|}{ ADF Intercept \& Trend } & \multirow{4}{*}{ Decision } \\
\hline & \multicolumn{2}{|c|}{ Level } & \multicolumn{2}{|c|}{$1^{\text {st }}$ Difference } & \\
\hline & $\overline{\mathrm{ADF}}$ statistic & Level probability & ADF statistic $1^{\text {st }}$ & Difference & \\
\hline & & & Difference & Probability & \\
\hline $\ln G D P_{t}$ & -1.403114 & 0.8385 & $-3.777692 * *$ & 0.0327 & I (1) \\
\hline $\ln P R I_{t}$ & -1.851417 & 0.6542 & $-5.613023 * * *$ & 0.0004 & I (1) \\
\hline $\operatorname{lnSEC} C_{t}$ & -2.547787 & 0.3048 & $-4.773962 * * *$ & 0.0034 & I (1) \\
\hline $\operatorname{lnTER} R_{t}$ & -0.587100 & 0.9725 & $-4.7030329 * * *$ & 0.0037 & $\mathrm{I}(1)$ \\
\hline $\ln G F I X_{t}$ & -1.971629 & 0.5918 & $-4.008639 * * *$ & 0.0198 & I $(1$ \\
\hline $\ln L F R C E_{t}$ & -2.761150 & 0.2214 & $-4.759265 * * *$ & 0.0038 & $\mathrm{I}(1)$ \\
\hline
\end{tabular}

Source: WDI, Authors' estimates using EViews 9

Note: (i) The ADF statistics were generated from a random walk model with drift and trend (ii) The lag length is determined through the Akaike Information Criterion (AIC) (iii) $* * * P<0.01$ $* * \mathrm{P}<0.05, * \mathrm{P}<0.1$ 
After validating that none of the relevant series is $\mathrm{I}(2)$, the following stage involves estimating the ARDL model. However, before applying the ARDL model, it is proper to determine the appropriate lag length using the Akaike Information Criterion (AIC). Figure 2 reports the recursive search of the ARDL model using the general to a specific approach (Gets). Accordingly, the results reveal that ARDL $[1,0,1,0,0,0]$ is the appropriate model from the data generating process (DGP).

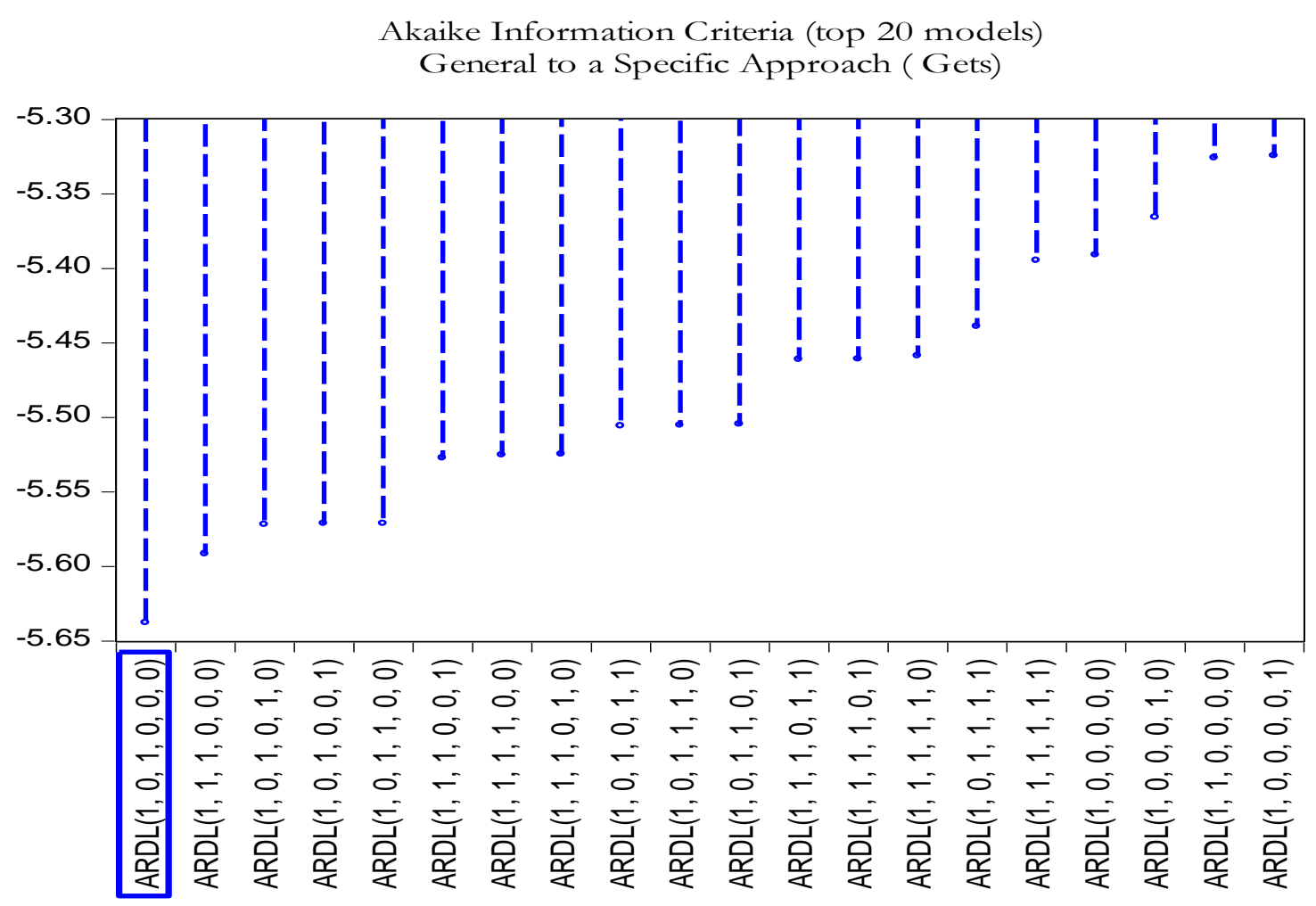

Figure 2. ARDL Model Selection

Source: WDI, Authors' Estimate using EViews 9

\subsection{Bounds Test Results}

The bound test results in Table 3 indicates that the F-statistics (4.8965) surpasses the critical upper bound (3.79) at the conventional (1, 5 and 10) percent significant level, affirming that the human capital composition and economic growth have a long run relationship in Indonesia.

Table 3. Test for Existence of Long Run Relationship

\begin{tabular}{cccc}
\hline & \multicolumn{2}{c}{ Dependent variable: $\ln G D P_{t}$} & \\
\cline { 2 - 3 } & \multicolumn{2}{c}{$\begin{array}{c}\text { F- statistics }=4.8965 \mathrm{~K}=5 \\
\text { Critical Value }\end{array}$} & \\
\cline { 2 - 3 } Significant level & Lower bound I (0) & Cointegrated \\
\hline $1 \%$ & 3.31 & 4.68 & Cointegrated \\
$5 \%$ & 2.62 & 3.79 & Cointegrated \\
\hline $10 \%$ & 2.26 & 3.35 & \\
\hline
\end{tabular}

Source: WDI, Authors' estimates using EViews 9

Note: (i) K denotes the number of independent variables 


\subsection{Short Run and Long Run Coefficients}

After confirming the existence of a cointegration relationship with the F-statistics. The results also provide the rationale for estimating the long-run and short-run elasticity of the Lucas (1988) endogenous growth model (See Table 4 below). Notably, the diagnostic test in Table 4 (below) indicates that the model is well specified since none of the statistics shown in the table is significant at 5\% significant level. Thus, the estimated ARDL model $[1,0,1,0,0,0]$ fulfils the condition of non-autocorrelation, homoscedasticity, the normality of the residuals, no model misspecification, and stability of the model during the period under consideration. Hence, the envisaged model can be acknowledged as a tentatively adequate calibration of the DGP.

Table 4. The Short Run Elasticity of The ARDL Model

\begin{tabular}{|c|c|c|c|c|}
\hline \multicolumn{5}{|c|}{ ARDL $[1,0,1,0,0,0]$ Based on AIC (Akaike Information Criteria) } \\
\hline \multicolumn{5}{|c|}{ Dependent variable: $\ln G D P_{t}$} \\
\hline Explanatory variable & Coefficient & Standard errors & T-value & P-value \\
\hline$\Delta \ln P R I_{t}$ & 0.173137 & 0.223709 & 0.773939 & 0.4472 \\
\hline$\Delta \ln S E C_{t}$ & 0.006985 & 0.063211 & 0.110508 & 0.9130 \\
\hline$\Delta \ln T E R_{t}$ & $0.004112 * * *$ & 0.001367 & 3.007942 & 0.0065 \\
\hline$\Delta \ln G F I X_{t}$ & $0.258069 * * *$ & 0.019045 & 13.55067 & 0.0000 \\
\hline$\Delta \ln L F R C E_{t}$ & $0.854710^{* * *}$ & 0.089364 & 9.564369 & 0.0000 \\
\hline $\operatorname{ECT}(-1)$ & $-0.808843 * * *$ & 0.057129 & -14.15813 & 0.0000 \\
\hline Diagnostic Test & & & \multicolumn{2}{|l|}{ Remarks } \\
\hline$\chi_{\text {LM test }}^{2}$ & & $3.387326[0.1838]$ & \multicolumn{2}{|c|}{ No serial correlation } \\
\hline$\chi_{A R C H}^{2}$ & \multicolumn{2}{|l|}{0.461657 [0.4969] } & \multicolumn{2}{|c|}{ No Heteroskedasticity } \\
\hline$\chi_{J B}^{2}$ & \multicolumn{2}{|l|}{$1.648277[0.4502]$} & \multicolumn{2}{|c|}{ Normal } \\
\hline$\chi_{\text {RAMSEY TEST }}^{2}$ & \multicolumn{2}{|l|}{$0.157077[0.6959]$} & \multicolumn{2}{|c|}{ No Misspecification } \\
\hline Stability $_{\text {CuSUM }}$ & \multicolumn{2}{|l|}{ S } & \multicolumn{2}{|c|}{ Stable } \\
\hline Stability $_{\text {CUSUMSQ }}$ & \multicolumn{2}{|l|}{ S } & \multicolumn{2}{|c|}{ Stable } \\
\hline
\end{tabular}

Source: WDI, Author's Estimates Using EViews 9

Note: The asterisk denotes rejection $* * * \mathrm{P}<0.01 * * \mathrm{P}<0.05, * \mathrm{P}<0.1$ (ii) $\mathrm{S}$ denotes Stability

The results of the ECM imply that most of the coefficients; tertiary education $\left(\Delta \operatorname{lnTER_{t}}\right)$, gross fixed capital formation $\left(\Delta \ln G F I X_{t}\right)$, and labor force $\left(\Delta \ln L F R C E_{t}\right)$ are positive and statistically significant to economic growth $\left(\ln G D P_{t}\right)$, except for primary school education $\left(\Delta \ln P R I_{t}\right)$ and secondary education $\left(\Delta \operatorname{lnSEC} C_{t}\right)$ indicated a positive and statistically insignificant effect to economic growth in the short run. Also, it worth stating that these elasticities are lower compared to the long-run coefficients (in Table 5). The ECT(-1) which denotes a one period lagged residual saved from the estimated dynamic long-run relationship is negative and significant at conventional $5 \%$ significant level, ensuring that convergence to long-run equilibrium can be attained. Moreover, scholars like; Banerjee, Dolado, and Mestre (1996) claimed that a highly significance of the $E C T(-1)$ vehemently proofs the existence of the long-run relationship. The speed of convergence is -0.808845 , which implies that around $81 \%$ deviations from long-run equilibrium are adjusted every year and the rest $19 \%$ in the subsequent year. It also means that once disequilibrium happens, it will take more than one year to adjust to equilibrium. Table 5 reports the long-run elasticity of the augmented version of Lucas (1988) endogenous growth model. 
Table 5. The Long Run Elasticity of The ARDL Model

\begin{tabular}{ccccc}
\hline \multicolumn{5}{c}{ ARDL $[1,0,1,0,0,0]$ Based on AIC (Akaike Information Criteria) } \\
\hline \multicolumn{5}{c}{ Dependent variable: $\ln G D P_{t}$} \\
\hline Explanatory variable & Coefficient & Standard errors & T-value & P-value \\
\hline $\ln P R I_{t}$ & 0.214055 & 0.280025 & 0.764413 & 0.4527 \\
$\ln S E C_{t}$ & $-0.181170^{* * *}$ & 0.055890 & -3.241573 & 0.0037 \\
$\ln T E R_{t}$ & $0.005084^{* * *}$ & 0.001592 & 3.192562 & 0.0042 \\
$\ln G F I X_{t}$ & $0.319059^{* * *}$ & 0.015002 & 21.267680 & 0.0000 \\
$\ln L F R E_{t}$ & $1.056706^{* * *}$ & 0.093269 & 11.329614 & 0.0000 \\
$C$ & $-11.6341^{* * *}$ & 0.057129 & -14.158136 & 0.0000 \\
\hline
\end{tabular}

Source: WDI, Author's Estimates Using EViews 9

Note: The asterisk denotes rejection $* * * \mathrm{P}<0.01 * * \mathrm{P}<0.05$, $* \mathrm{P}<0.1$

The long-run elasticity results presented in Table 5 confirms that tertiary school education $\left(\ln T E R_{t}\right)$, gross fixed capital formation $\left(\ln G F I X_{t}\right)$ and the labor force $\left(\ln L F R C E_{t}\right)$ are statistically significant and positively affecting economic growth $\left(\ln G D P_{t}\right)$. However, secondary school $\left(\ln S E C_{t}\right)$ education is found to have a statistically significant adverse effect to economic growth. The remaining variable; primary education $\left(\ln P R I_{t}\right)$ is found to have a positive and statistically insignificant effect to economic growth in Indonesia.

\subsection{Discussion}

From the above analysis, primary education is not significant in explaining both the short-run and long-run economic growth. The findings contradict that of McMahon (1998) that primary education has a significant effect to the Indonesian economic growth. Perhaps one possible and visible justification is that; chronic challenges remain in the quality of primary education in Indonesia. The performance of Indonesia in various international competition programs has undercover the related issues in education; mathematics, science, and literacy. More to that, there had been a significant disparity in educational services within the country with the eastern part lagging behind, especially. As far as education is a concern, people in these areas lack books, equipment's, and curriculum guide with most of the primary schools lacking electricity, which has implications to technology and e-learning accessibility (see Hendayana, Supriatna, and Imansyah, 2010).

Again, secondary school education indicates an adverse and significant impact to the economic growth of Indonesia in the long-run. This result again contradicts the findings of Kasri (2011) that secondary school education has a positive effect on Indonesia. One possible explanation is perhaps Indonesia has a concentrated spectrum of occupations within its labor force, with many workers having low levels of educational attainment and being employed in low skill occupations. Most of the employed population have junior high school or less as their highest level of educational achievement and still work as agricultural laborers, production laborers or as low skilled service sector workers. Indeed, given the demand for semi-skilled workers will increase from today 55 million to 113 million in the year 2030 is expected to cause skilled shortage, skilled mismatched worsen the economy (see Oberman et al., 2012). Apart from the already mention challenges, in Indonesia, secondary school education total spending is low relative to other countries in the region, Southeast Asia specifically.

Finally, tertiary education, gross fixed capital formation, and the labor force have a positive and significant effect to the economic growth of Indonesia both in the short run and long run, thus fulfilling the prophecy of Lucas (1988) endogenous growth model. Perhaps a visible justification is that, in Indonesia, considering the real sector, a worker with a diploma or 
university education are more actively participating in training course compared to a worker with secondary or primary education (see Figure 3 ).

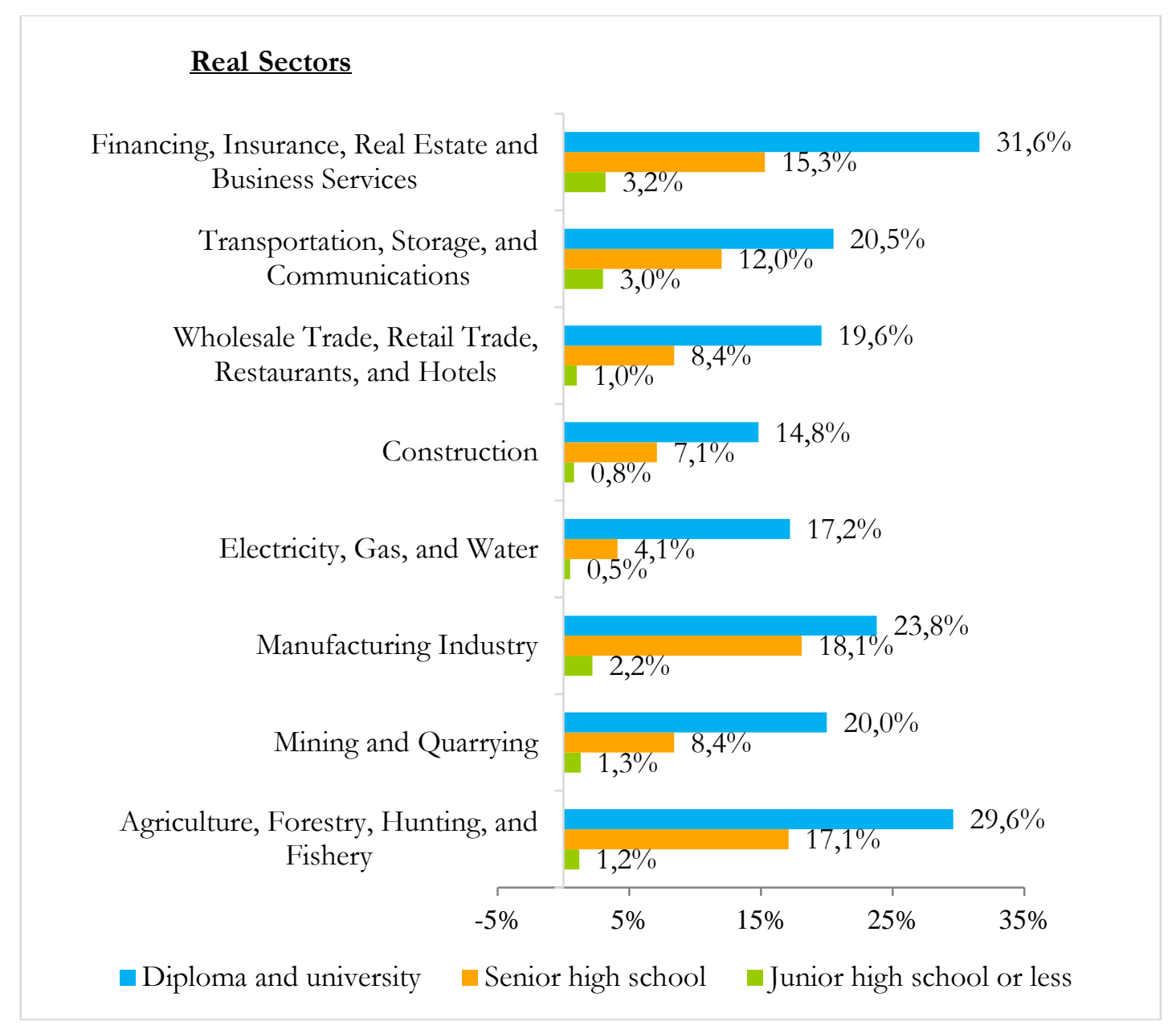

Figure 3. Participation in Certified Training Course by Human Capital Composition in Indonesia

Source: Data from Allen ( 2016 p.13), Author's graphical representation

Note: Note all values in $\%$ of the employed population

\section{Conclusion}

This paper attempts to investigate the relationship between the human capital composition and economic growth in Indonesia for the period 1984-2014 empirically. The paper used the augmented version of the Lucas (1988) endogenous growth model and employed the Autoregressive Distributed Lag (ARDL) model. The results indicate that human capital composition and economic growth are cointegrated. The estimates of long-run and short-run elasticity of the different education level suggest, overall, human capital structure in Indonesia is still at the stage of promoting economic growth and identifies tertiary education as the main level for development and thus fulfilling the prophecy of Lucas (1988). Consequently, as for policy implication, the results suggest the following recommendations:

Firstly, at the primary level, policies must be directed to the improvement of education quality instead of putting much emphasis on the enrolment rates. More to that, the improvement in infrastructure, the establishment of classroom well equipped with learning materials 
alongside the adequate supply of well-trained teachers is essential. In doing so, it will help increase the efficiency of the student at the primary level.

Secondly, for the secondary and tertiary level, policies must focus on enrolment rates, increasing budgetary spending on education, along with addressing the issues of education quality, and embracing digitization of the education system. At this level, subsidizing education, encouraging research and development, improving internet connection in remote higher education institutions, improve the accessibility of electronic journals, promote virtual teaching platform, engaging in training the teachers/ lecturers and the students on how to utilize available updated online tools/software's. Of course, Indonesia cannot afford to be left behind in this era of digitization. As a result, the secondary and tertiary level curriculum must be designed for the students to learn how to "code and demonstrate basic computer programming".

\section{REFERENCES}

Ahmed, M. U., Muzib, M., \& Roy, A. (2013). Price-Wage Spiral in Bangladesh: Evidence from ARDL Bound Testing Approach. International Journal of Applied Economics, 10(September), 77-103.

Allen, E. R. (2016). Analysis of Trends and Challenges in the Indonesian Labor Market. ADB Papers on Indonesia.

Altbach, P. G., \& Umakoshi, T. (2004). Asian universities: historical perspectives and contemporary challenges. Johns Hopkins University, Press.

Asian Development Bank. (2015). Reviews of National Policies for Education: Education in Indonesia - Rising to the Challenge. OECD. https://doi.org/10.1787/9789264230750-en

Asteriou, D., \& Agiomirgianakis, G. M. (2001). Human capital and economic growth Time series evidence from Greece. Journal of Policy Modeling. Retrieved from http://isiarticles.com/bundles/Article/pre/pdf/18387.pdf

Azariadis, C., \& Drazen, A. (1990). Threshold Externalities in Economic Development. The Quarterly Journal of Economics, 105(2), 501. https://doi.org/10.2307/2937797

Banerjee, A., Dolado, J. J., \& Mestre, R. (1996). Error-Correction Mechanism Tests for Cointegration in a Single-equation Framework. Journal of Time Series Analysis, 19(1995), 1-17.

Bayhaqi, A. (2000). Education and Macroeconomic Performance in Indonesia: A Comparison with Other ASEAN. Institute of Southeast Asian Studies (ISEAS) Visiting Researches Series, No.13., 13(13).

Benhabib, J., \& Spiegel, M. M. (1994). The role of human capital in economic development evidence from aggregate cross-country data. Journal of Monetary Economics, 34(2), 143-173. Retrieved from https://ideas.repec.org/a/eee/moneco/v34y1994i2p143173.html

Benos, N., \& Karagiannis, S. (2016). Do education quality and spillovers matter? Evidence on human capital and productivity in Greece. Economic Modelling, 54, 563-573. https://doi.org/10.1016/j.econmod.2016.01.015

Bouaissa, M. (2009). Human Capital Theory, Returns to Education and on-the-Job Learning: Evidence from Canadian Data. Preliminary and Incomplete Version, CEA, 43rd Annual Conference, University of Toronto, Ontario, May 29-31, 2009, (2007), 1-20.

Chi, W. (2008). The role of human capital in China's economic development: review and new evidence. China Economic Review, 19, 421-436.

Dharma, A. (2008). Indonesian Basic Education Curriculum Current Content and Reform. Retrieved from http://www.ibe.unesco.org/curricula/indonesia/io_befw_2008_eng.pdf

Elias, S., \& Noone, C. (2016). The Growth and Development of the Indonesian Economy, 3344. 
Feldman, M., Hadjimichael, T., \& Lanahan, L. (2016). The logic of economic development: a definition and model for investment. Environment and Planning C: Government and Policy, 34(1), 5-21. https://doi.org/10.1177/0263774X15614653

Firman, H., \& Tola, B. (2008). The Future of Schooling in Indonesia. Journal of International Cooperation in Education, 11(1), 71-84.

Hassan, S., \& Ahmed, H. (2008). Education's contribution to the economic growth of SubSaharan Africa. Southwestern Economic Review, 175-190.

Hawkes, D., \& Ugur, M. (2012). Evidence on the relationship between education, skills and economic growth in low-income countries: A systematic review.

Hendayana, S., Supriatna, A., \& Imansyah, H. (2010). Indonesia's Issues and Challenges on Quality Improvement of Mathematics and Science Education. Indonesia University of Education, 41-51.

Kasri, R. A. (2011). Time series Evidence on Education and Economic Growth. Economic Journal of Emerging Market, 3(2), 109-123.

Kawuryan, A. (2001). Institutional Development and Economic Growth: Human Capital in Indonesia, 1900 -2000. Working Paper, International Institute of Social History.

Krueger, A. B., \& Lindahl, M. (2001). Education for Growth: Why and for Whom? Journal of Economic Literature, 39(4), 1101-1136. https://doi.org/10.1257/jel.39.4.1101

Lau, C. K. M. (2010). New evidence about regional income divergence in China. China Economic Review, 21(2), 293-309. https://doi.org/10.1016/j.chieco.2010.01.003

Lucas, R. E. (1988). On the mechanics of economic development. Journal of Monetary Economics, 22(1), 3-42. https://doi.org/10.1016/0304-3932(88)90168-7

Mahadeva, L., \& Robinson, P. (2004). Unit root testing to help model building. Centre for Central Banking Studies, Bank of England. Retrieved from https://mafiadoc.com/unitroot-testing-to-help-model-building-bank-ofengland_597887f81723dde28b57e096.html

Mankiw, N. G., Romer, D., \& Weill, D. N. (1992). A contribution to the empirics of economic growth. Quarterly Journal of Economics, 107(2), 407-437. https://doi.org/10.1016/j.jpolmod.2014.01.001

McMahon, W. W. (1998). Education and growth in East Asia. Economics of Education Review, 17(2), 159-172. https://doi.org/10.1016/S0272-7757(97)00050-2

Miller, R. (2007). Education and Economic Growth: From the 19th to the 21 Century. Cisco Systems. https://doi.org/6/8/16

Mincer, J. A. (1974). Introduction to "Schooling, Experience, and Earnings. Columbia University Press. Retrieved from http://www.nber.org/chapters/c1762

Moeliodihardjo, B. Y. (2015). Higher Education in Indonesia. International Seminar on Massification of Higher Education in Large Academic Systems. https://doi.org/10.1080/03062848608729650

Nelson, R. R., \& Phelps, E. S. (1966). Investment in Humans, Technological Diffusion, and Economic Growth. The American Economic Review, 56(1/2), 69-75. Retrieved from https://www.jstor.org/stable/pdf/1821269.pdf

Oberman, R., Dobbs, R., Budiman, A., Thoman. Fraser, \& Rose, M. (2012). The Archipelago Economy: Unleashing Indonesia's Potential. The McKinsey Global Institute. Retrieved from www.mckinsey.com/mgi.

Odit, M. P., Dookhan, K., \& Fauzel, S. (2010). The Impact of Education on Economic Growth: The Case of Mauritius. International Business \& Economics Research Journal (IBER), 9(8), 141-152. https://doi.org/10.19030/iber.v9i8.620

Pereira, J., \& Aubyn, M. St. (2004). What level of education matters most for growth? Evidence from Portugal. Working Papers Department of Economics 2004/13, ISEG - Lisbon School of Economics and Management, Department of Economics, Universidade de Lisboa. 
Pesaran, M. H., Shin, Y., \& Smith, R. J. (1999). Bounds Testing Approach to Analysis of long Run Relationships. Cambridge Working Papers in Economics 9907, Faculty of Economics, University of Cambridge.

Pesaran, M. H., Shin, Y., \& Smith, R. J. (2001). Bounds testing approaches to the analysis of level relationships. Journal of Applied Econometrics, 16(3), 289-326. https://doi.org/10.1002/jae.616

Psacharopoulos, G. (1995). The Profitability of Investment in Education: Concepts and Methods. The World Bank, Human Capital Development, Working Papers, No.76., (November), 1-22. https://doi.org/10.1017/CBO9781107415324.004

Ramcharan, R. (2004). Higher or basic education? The composition of human capital and economic development. IMF Staff Papers, Vol. 51, No. 2, 51(2), 309-326.

Reza, F., \& Widodo, T. (2013). The Impact of Education on Economic Growth in Indonesia. Journal of Indonesian Economy and Business, 28(1), 1-30. Retrieved from http://www.ssc.wisc.edu/ munia/475/dahlin0202.pdf

Self, S., \& Grabowski, R. (2004). Does education at all levels cause growth? India, a case study. Economics of Education Review, 23(1), 47-55. https://doi.org/10.1016/S02727757(03)00045-1

Zhang, C., \& Zhuang, L. (2011). The composition of human capital and economic growth: Evidence from China using dynamic panel data analysis. China Economic Review, 22(1), 165-171. https://doi.org/10.1016/j.chieco.2010.11.001

\section{Appendix}
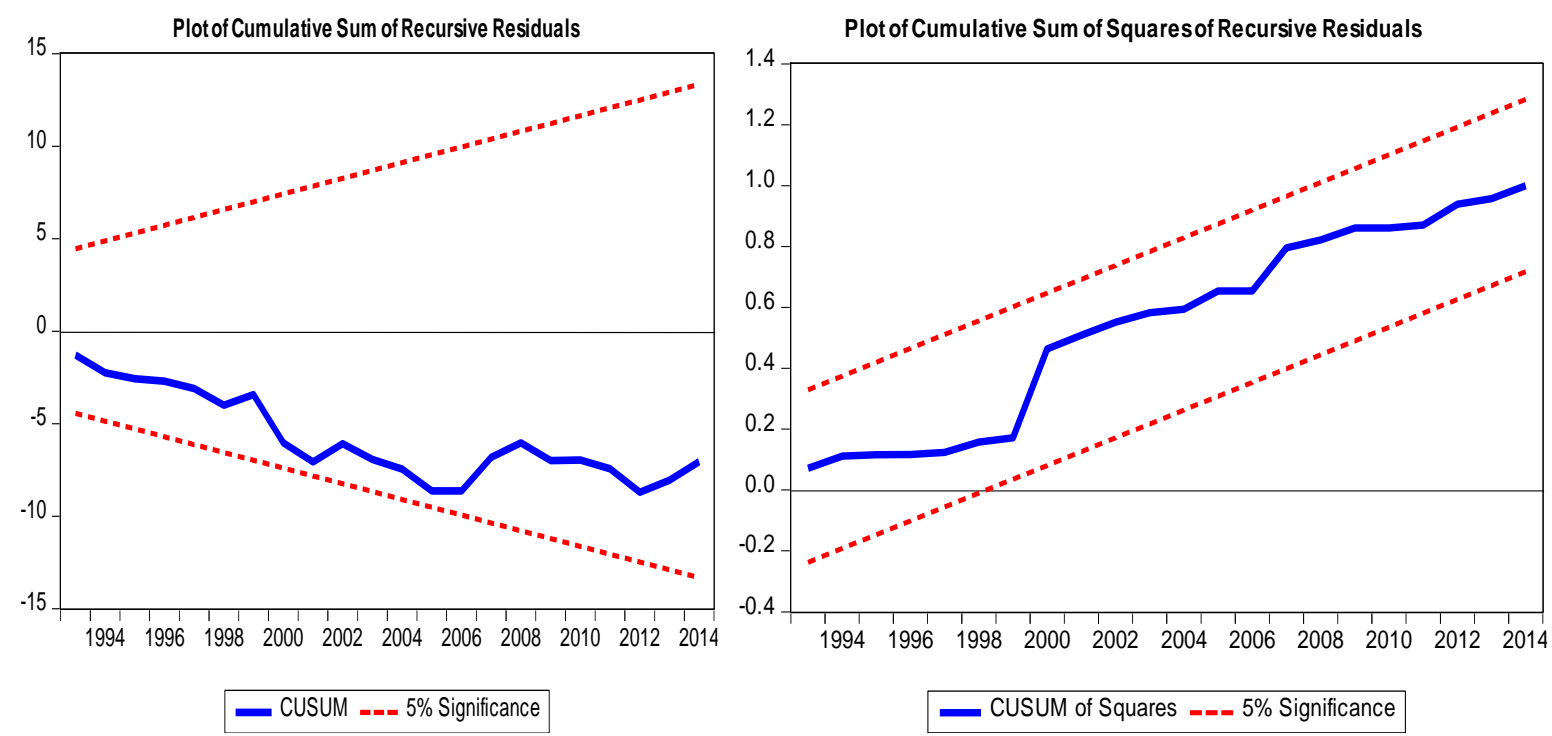

Note: (i) The red lines signify the critical bound at 5\% significant level. (ii) Only the residual from 1994 to 2014 is reported due to the loss of the sample as a result of the Lags variables in the ARDL model. 